\title{
OFFER OF AUTHENTIC FOOD AS A CONDITION FOR GASTRONOMIC TOURISM DEVELOPMENT
}

\author{
Bojana Kalenjuk ${ }^{1 *}$, Dragan Tešanović ${ }^{1}$, Snježana Gagić ${ }^{2}$, \\ Irma Erdeji ${ }^{1}$, Maja Banjac ${ }^{1}$ \\ ${ }^{1}$ Faculty of Sciences, University of Novi Sad, Serbia \\ ${ }^{2}$ College of Professional Studies in Management and Business Communications, \\ Sremski Karlovci, Serbia
}

\begin{abstract}
:
By perceiving the food as an important part of the tourism offer in terms of biological needs of tourists, the question arises as to how it can be further exploited to contribute to tourism development. In this regard, food prepared using the local ingredients, according to the old methods of processing and serving, and in an authentic way, can be of interest to the tourists of selective forms of tourism, also known as food tourism, gastronomic tourism and gourmet tourism. The research aims to demonstrate the quality of food offer in the hospitality industry of Vojvodina and examine whether it can meet the requirements of foreign tourists who travel for it. The survey was conducted in 147 catering facilities in Vojvodina offering food and beverages, by means of direct and indirect collecting of written offers, and includes the statistical analysis of 10,923 meals. The aim is to indicate the current state of gastronomic offer and all advantages of authentic food and gastronomic tourism.
\end{abstract}

\section{Key words:}

food, gastronomy, tourism, gastronomic tourism.

\section{INTRODUCTION}

The regions in which the wave of technology and globalization did not change the way food and beverages are served and prepared, including the consumption culture, have become favorable for development of selective forms of tourism, also known as food and drink tourism, culinary tourism, gastronomic tourism, gustatory tourism and gourmet tourism (Hall \& Mitchell, 2002).

These forms represent a special form of tourism whose aim is to attract tourists motivated by food and drinks in different ways, thus making food an important tool of the tourism industry (Hall \& Mitchell, 2000), which in order to develop and grow further has to offer something different. The focus of gastronomic tourists are local and national dishes (Kalenjuk et al., 2012a, 2012b; Kalenjuk et al., 2014), which as such are the reflection of a people's culture.
Gastronomic tourism is an experience pursued by visiting and tasting food and beverages at primary or secondary producers', visiting food and beverage festivals and consuming authentic specialties in various restaurants. An increasingly popular form of gastronomic tourism is an activity of tourists who attend different multi-day schools of authentic regional cooking (Hall \& Mitchell, 2006).

The authors define it as a journey during which the purchase or consumption of regional food (and drink), or observation and study of food production (from agriculture to culinary school), represents an important motive or activity (Ignatov \& Smith, 2006). Culinary tourists visit places that offer unique culinary experiences. They love to get into their host's kitchen, inquire about the typical dishes, and learn where they can purchase ingredients and spices needed for a particular meal (Kalenjuk et al., 2012a). 
The popularity of tourism for food and beverage has been known in the world for several decades (Santich, 2004). However, it has recently become a trend in Vojvodina. In the previous development policies and concepts related to tourism development, gastronomy i.e. food of locals and tourists, was not given the adequate development role, as opposed to its basic merits (Kalenjuk et al., 2013). However, the development and standards of food for tourists are not always determined by tourism policy, but national, economic, agricultural and food policies (Hjalager \& Corigliano, 2000).

Food and tourism are integral parts of agro-tourism, wine tourism, through sale of agricultural, alimentary and gastronomic products.

The research will show the quality of food in the hospitality industry of Vojvodina, and whether it is able to please the interests of foreign tourists traveling for its sake. The aim of the paper is to draw attention to the current state of gastronomy, as the basis for development of gastronomic tourism in the region.

\section{LITERATURE REVIEW}

\section{Relationship between food and tourism}

Tourism is a branch of economy which has significant social and economic functions, and is an integral factor of socio-cultural development. Tourist activation of certain space contributes to highlighting and better evaluation of other values of the environment in which food is an essential resource (Henderson, 2004; Quan \& Wang, 2004).

The authors note the particular importance of food as a physiological need, considering that expenses for food and drink in tourism account for one third of total tourist spending of global tourist traffic (Meler \& Cerović, 2003). Therefore, the relationship between food and tourism is one of the most important issues in the region.

Beardsworth and Keil explain that nutritional intake is not the only goal of food consumption, and add that it also includes a gustatory experience and interaction with other people during consumption (Beardsworth \& Keil, 1997). Thus, the use of food for special occasions and festivals can represent the cultural and spiritual identity of people. Furthermore, its role is associated with the status and social classes of individuals, which is often closely related to the type of restaurants they visit.
Studies have shown that among all the possible costs during the trip, tourists are least willing to reduce the budget intended for food. This suggests that tourist food consumption makes a significant contribution to local restaurants, steakhouses, bakeries, pastry shops, agriculture and food industries, and thus the economy of the destination (Pyo et al., 1991). This is not only about the consumption of culinary products, which are, as such, in their final form, offered to tourists, but also about the consumption of agricultural and food products in the region (Kalenjuk et al., 2011).

Food can also be the main instigator and primary motive that meets a multitude of needs and desires (Tikkanen, 2007). Food has been recognized on the tourism market as (Hall \& Mitchell, 2001):

- part of the local culture, consumed by tourists;

- part of the tourism promotion;

- potential component of the local agricultural and economic development, and

- regional factor affected by consumption patterns and perceived desires of tourists.

\section{Gastronomic tourism}

Hall and Mitchell define gastronomic tourism as visiting primary or secondary food producers, food festivals, catering facilities for production and serving of food and certain destinations for tasting and/or experiencing attributes of regional specialties, where food is the primary motive to travel (Hall \& Mitchell, 1996). Gastronomic tourism is defined as the activity of exploration and discovery of the culture and history through food, which affects the formation of unforgettable experiences (Long, 2004). Thus, gastronomy connects and incorporates other forms of tourism (Stojanović \& Čerović, 2008).

Various terms are related to different forms of tourist movements motivated by food and beverages, among which are:

- gastronomic tourism (Hjalanger \& Richards, 2002);

- culinary tourism (Wolf, 2006; Ignatov \& Smith, 2006);

- gustatory tourism (Boniface, 2003) and

- food tourism (Hall et al., 2003).

By definitions, the "culinary" focuses only on styles of food preparation while "gastronomy" deals with the 
consumption of food and beverages in a more general sense and tasting good food and beverages as part of a luxurious lifestyle. The word "culinary" (culinarius) tends to emphasize the style of food preparation and consumption, as well as the social context in which food is ordered, prepared and consumed. Therefore, "culinary" can refer to ingredients, prepared food, beverages, food production, motives, activities, institutional structures and food tourism itself (Ignatov \& Smith, 2006).

The authors note that gastronomic tourism is different from agro-tourism as it is a subset of cultural tourism (cuisine is part of the culture), and agrotourism is a subset of rural tourism, but also a subset of gastronomic tourism. Surely, gastronomic tourism and agro-tourism are inextricably linked. Similarly, some authors consider wine and beer tourism as subsets of gastronomic tourism because this type of tourism includes the consumption of beverages, both alcoholic and non-alcoholic (Hall, 2003; Wolf, 2006), such as tea tourism, although wine tourism is studied independently.

Unlike many other forms of tourist movements, gastronomic destinations are usually available yearround at any time of the day and in all weather conditions (Richards, 2002), noting the importance of authentic food offer in restaurants.

\section{Structure of food offer in catering industry}

Only authentic offer of dishes can satisfy the curiosity of gastronomic tourists, such as local and regional dishes. The authors classify the dishes included in the offer of catering facilities, on the basis of their origin, as: local, national and international, bearing in mind that the ratio of all three should be equal, as it is the only way in which it is possible to meet the demand of all types of consumers (Tešanović et al., 2010; Kalenjuk et al., 2012b). The kind of dishes that should, by all criteria, be included in catering facilities' offer and attract the attention of tourists motivated by food, are in the first place local dishes, followed by national (Kalenjuk et al., 2012c).

Local dishes are either prepared in households or are the specialties of a restaurant and a city, being made using the authentic, local foodstuffs. The examples would be "stuffed steak by chef Marko", "Leskovački voz", Novi Sad steak, Temerin steak, a specialty of Salaš 132 etc. These are usually named after a location or the creator of the recipe.
National or regional dishes are those which have taken root in a wide area of a country. There are many dilemmas over the food origin. Various nations have historically won other territories and brought along their own eating habits, culinary recipes, starting to make the dishes with ingredients from the conquered territory, but adding to them their own spices. Locals adopted such dishes as their own and passed them on from generation to generation and the dishes thrived. The dishes that have taken hold of a broader territory of a country, regardless of their country of origin, alongside the dishes that were developed on the country's territory, are considered national dishes. Such dishes include sarma, goulash, stew, roast pork, ćevapčići, Karađorđe's steak, cheese pie, burek and many other Serbian dishes. It often happens that a local dish is a national one as well, such as Leskovac grill. Moreover, a dish can be local, national and international at the same time, such as Viennese and Parisian steak (Tešanović et al., 2010).

International dishes are already affirmed dishes of various international cuisines that are worldwide accepted including: Tournedos Rossini, Italian minestrone, pizza, steak "Esterhazy", Kiev cutlet and countless other recognizable dishes in the global hospitality industry. They are prepared in restaurants for the tourists without an adventurous gastronomic spirit and those who do not like to experiment and prefer to eat local food during their stay in some other county.

Food offer is considered adequate if the facility has at least $30 \%$ of local and $30 \%$ of national products, while the rest is comprised of those of international origin. In order to ensure the development of gastronomic tourism, it is better to offer more local and national dishes and beverages (Tešanović \& Koprivica, 2007).

\section{METHODOLOGY}

In order to obtain necessary information on the structure of food offered by catering facilities, direct and indirect collection of written offers (menus) was conducted by means of random sampling, during the period from March 2011 until March 2013.

The analysis and synthesis was performed on a sample of 10,923 meals in 147 catering facilities throughout Vojvodina. Based on the origin, dishes were grouped into local, national and international, after which a statistical observation was performed.

Statistically processed data, i.e. absolute frequen$\mathrm{cy}$, relative frequency, minimum value, maximum 
value, means, standard deviation, coefficient of variation along with discussion are presented in the paper in the form of a table and a graph.

\section{RESULTS AND DISCUSSION}

\section{The analysis of authentic food offer}

McKercher et al. (2008) emphasize the importance of local, authentic dishes and formation of a unique offer in catering facilities for successful development of gastronomic tourism (McKercher et al., 2008). Table 1 shows the data obtained by analyzing meals per groups in 147 catering facilities, with a minimum and maximum number of dishes, standard deviation, and coefficient of variation for the observed group of dishes, depending on the origin of the recipe.

By analyzing the structure, it was concluded that local dishes do not have a satisfactory share in the offer of any food group and that these dishes are represented in a significant percentage in the offer of cold appetizers with $20.86 \%(n=199)$, with restaurants often offering homemade dried meat products and vegetables. International appetizers are most frequent with $44.17 \%(\mathrm{n}=429)$ and are composed of prosciutto served with melon, salmon carpaccio, caviar, cheese platters. National specialties, primarily „Vojvođanska zakuska“, are represented with a share of $34.17 \%(n=326)$, which is quite satisfactory.

In addition to cold appetizers, ready-made meals of various types of meat have a similar share of $19.40 \%(\mathrm{n}=77)$, while international dishes are represented in a small percentage of $21.41 \%(n=407)$. Ready-made meals offer is dominated by dishes of national origin, $59.19 \%(n=235)$, which can be considered satisfactory.

National dishes are represented in the offer of fish dishes with significant share of 52.97\% $(n=472)$ dominated by different specialties of river fish prepared in different ways, international dishes are represented with $40.74 \%(n=363)$, while local dishes account for the minimum of $8.66 \%(\mathrm{n}=56)$. This is followed by salads with $50.74 \%(\mathrm{n}=888)$, including "Shopska“ and "Serbian salad" as the most common ones, although these are not from Vojvodina, but are prepared and offered in addition to chutney, mixed salad and others (international with $45.89 \%(\mathrm{n}=803)$, local salads are represented by only $3.37 \%(n=59)$ ).

Significant representation of national dishes in the offer of dishes to order with $48,79 \%(n=1767)$ (in- ternational 41.28\% ( $\mathrm{n}=1495)$, local 9.94\% $(\mathrm{n}=360))$, soups and broths $49.21 \%(\mathrm{n}=280)$ (international $38.66 \%(\mathrm{n}=222)$, local $12.13 \%(\mathrm{n}=407))$ and desserts $45.17 \%(\mathrm{n}=533)$ (international 51.02\% $(\mathrm{n}=602)$, local $3.81 \%(n=45))$.

The largest share of international dishes is observed in the offer of side dishes and stews with $65.65 \%(n=407)$. It is not in favor of the development of culinary tourism that there is a great share of French fries in almost all restaurants, with a small share of other side dishes and stews based on potato, such as mashed potato. National side dishes and stews offer is twice lower and accounts for $29.68 \%$ $(\mathrm{n}=184)$, whereas side dishes and stews prepared according to the authentic recipes are represented to a very small extent, with a share of only $4.68 \%(n=29)$.

In the offer of hot appetizers, international specialties account for a considerable share of $68.66 \%$ $(\mathrm{n}=644)$. The restaurants have a satisfactory offer of cheese, au gratin pancakes and various types of pasta prepared according to Italian recipes, Milanese and Bolognese, ravioli. The research included grouped pizzas as well as pasta dishes, which contribute to the increase in the share of international dishes. National hot appetizers are represented by $25.80 \%(\mathrm{n}=242)$ and local hot appetizers by only $5.54 \%(\mathrm{n}=52)$.

Based on the number of meals within the catering facilities and coefficient of variation, we have observed considerable differences in the offer of all of the analyzed groups of dishes with a great variation in the offer of local dishes, dominated by the offer of hot appetizers with $294.44 \%$, fish dishes with $282,05 \%$ and side dishes and stews with $340.00 \%$, which is not justifiable as Vojvodina is the breadbasket of the country, with rivers full of fish that caterers can use to prepare a lot of authentic, regional specialties.

Based on the obtained data, it was noted that none of the groups of dishes within the entire region has satisfactory offer structure of dishes of $30 \%$. The share of national dishes is satisfactory for certain groups, such as soups and broths, ready-made meals and meals to order, but the share of local specialties is not satisfactory in terms of the gastronomic tourism development (Figure 1).

\section{The analysis of the overall offer of authentic food}

By analyzing the overall offer of meals in the surveyed catering facilities in Vojvodina, it was conclud- 


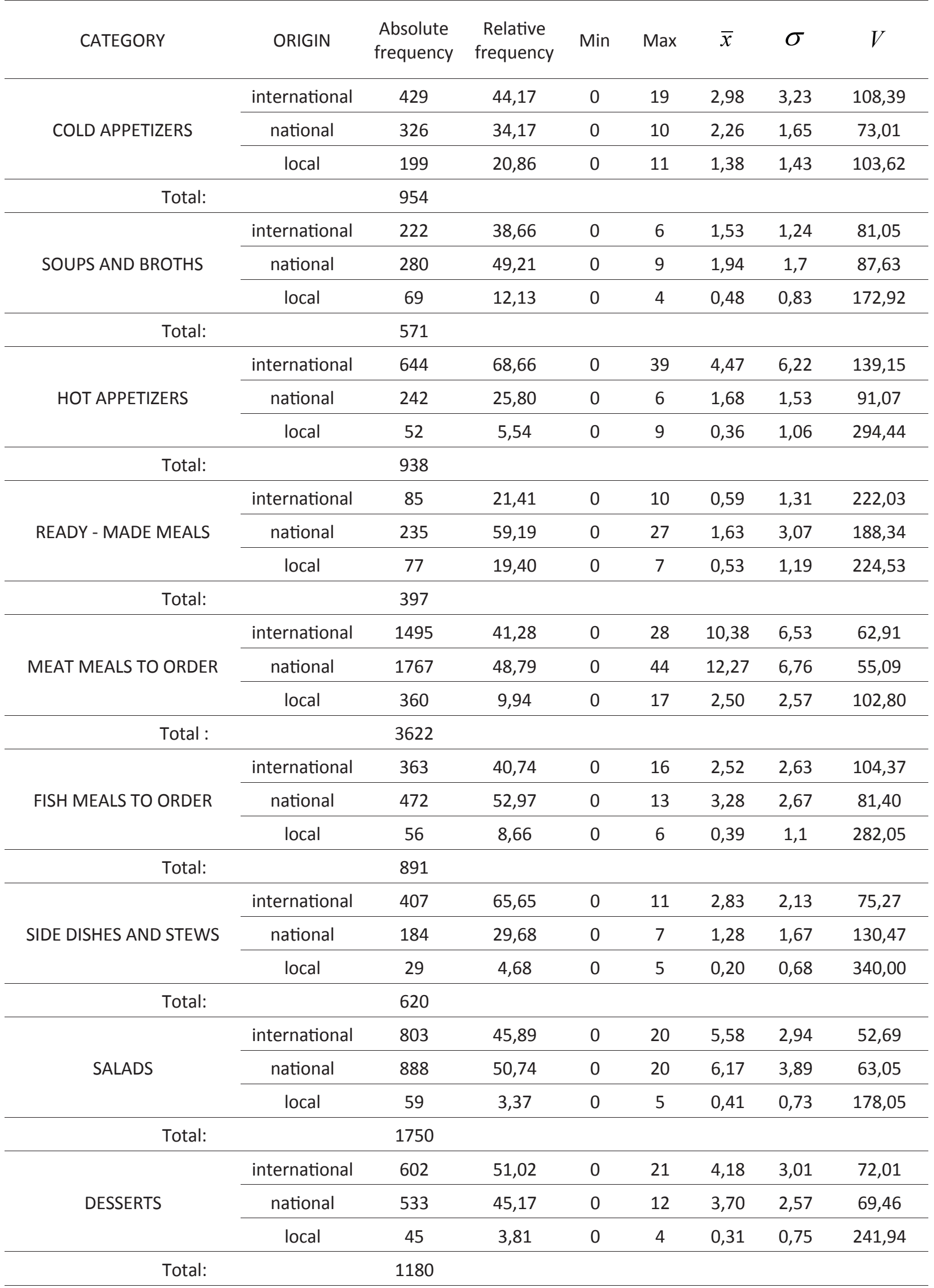

Table 1. The structure of food offer in the hospitality industry of Vojvodina 
ed that there is a large share of international dishes, and national dishes, $45.73 \%$, and $43.92 \%$, respectively, which is quite positive. The share of local dishes and creations by catering facilities and population is unsatisfactory and accounts for only $10.35 \%$ (Fig. 2).

Wood and Munoz state that tourists who visit the restaurants with national motives, seek authentic, ethnic and cultural experiences (Wood \& Munoz, 2007). Therefore, the authenticity of the offers may have a decisive impact on their overall satisfaction. If we take into account the recommendations of the authors, it can be concluded that the overall offer at the regional level is partially satisfactory, because of the satisfactory number of national specialties in the offer of side dishes (pasta dishes), ready-made meals and dishes to order (meat and river fish).

\section{CONCLUSION}

By consulting international literature in the field of gastronomic tourism, gastronomy and hospitality industry, and keeping up with the research conducted in the catering facilities in Vojvodina, we may conclude that the offer of dishes in the entire region has a large share of dishes of international and national origin, with nearly $46 \%$, and $44 \%$, respectively, which is quite satisfactory. The share of local dishes and creations by catering facilities is unsatisfactory and accounts for only $10 \%$.

By studying and following trends, places and roles of authentic food of developed tourism destinations worldwide, we may notice that Vojvodina faces with the growing issue of the non-systemic, insufficient

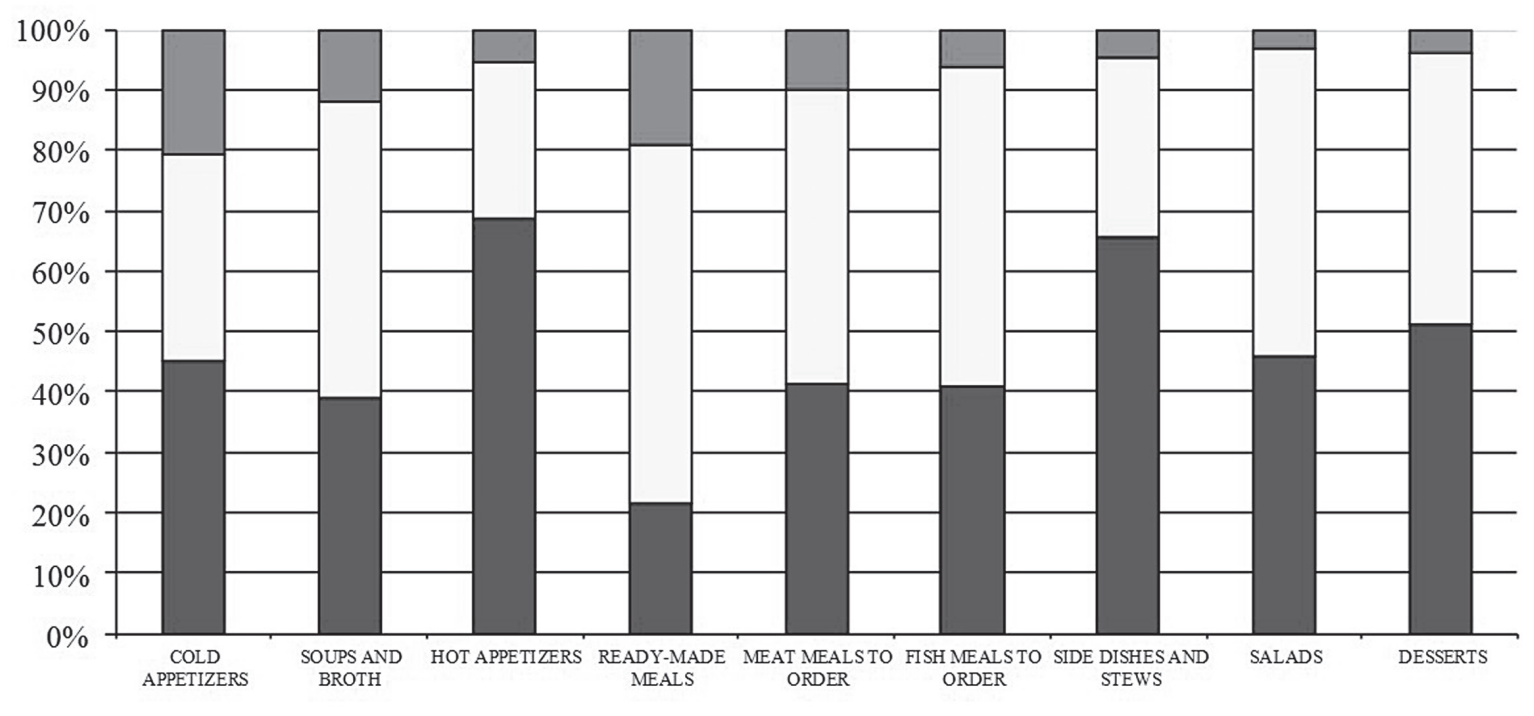

\section{घLOCAL DISHES $\square$ NATIONAL DISHES a INTERNATIONAL DISHES}

Figure 1. Food structure according to origin of recipe

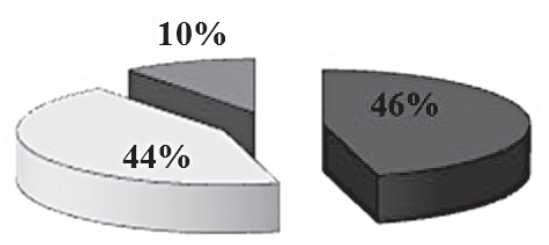

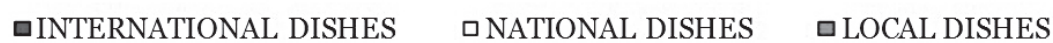


approach to a more successful placement of food resources in the active function of tourism development. By observing the region as a multicultural destination, a breadbasket of the country with extensive culinary heritage, restaurateurs are expected to introduce authentic dishes made with local ingredients, whose combinations of spices and methods of preparation and serving would intrigue and attract foreign tourists motivated by food. In order to ensure a successful development of gastronomic tourism, catering facilities on the territory of Vojvodina are requested to introduce local, regional, authentic delicacies for the sake of achieving the appropriate share of offer at the minimum level of $30 \%$.

Acknowledgements: This work is part of the research project: III-046009 and III-046005 funded by the Ministry of Science and Technological Development of the Republic of Serbia.

\section{REFERENCES}

Beardsworth, A., \& Keil, T. (1997). Sociology on the menu: An invitation to the study of food and society. London: Routledge.

Boniface, P. (2003). Tasting Tourism: Travelling for Food and Drink. Aldershot: Ashgate.

Hall, C.M. (1996). Wine tourism in New Zealand. In: Towards a more sustainable tourism: Proceedings of Tourism Down Under II: A tourism research conference, 3-6 December 1996. (pp. 109-119). Dunedin, NZ: Centre for Tourism, University of Otago.

Hall, C.M. (2003). Wine, Food, and Tourism Marketing. Binghamton, NY: Haworth Hospitality Press.

Hall, C.M., \& Mitchell, R. (2000). We are what we eat: Food, Tourism and Globalization. Tourism, Culture \& Communication, 2, 29-37.

Hall, C.M., \& Mitchell, R. (2001). Wine and food tourism. In N. Douglas, N. Douglas, \& R. Derrett (Eds.), Special Interest Tourism. Milton, Australia: John Wiley \& Sons.

Hall, C.M., \& Mitchell, R. (2002). The changing nature of the relationship between cuisine and tourism in Australia and New Zealand: From fusion cuisine to food networks. In A.-M. Hjalager \& G. Richards (Eds.), Tourism and Gastronomy. (pp. 188-206). London: Routledge.

Hall, C.M., \& Mitchell, R. (2006). Gastronomy, food and wine tourism. In D. Buhalis \& C. Costa (Eds.), Tourism Business Frontiers: Consumers, products and industry. Oxford: Elsevier.

Hall, C.M., Sharples, L., Mitchell, R., Macionis, N., \& Cambourne, B. (2003). Food tourism around the world: Development, management and markets. Oxford: Butterworth- Heinemann.
Henderson, J.C. (2004). Food as a tourism resource: A view from Singapore. Tourism Recreation Research, 29(3), 69-74.

Hjalager, A.-M., \& Corigliano, M.A. (2000). Food for tourists - determinants of an image. International Journal of Tourism Research, 2(4), 281-293. doi:10.1002/15221970(200007/08)2:4<281::AID-JTR228>3.0.CO;2-Y

Hjalager, A.-M., \& Richards, G. (2002). Tourism and Gastronomy. London: Routledge.

Ignatov, E., \& Smith, S. (2006). Segmenting Canadian Culinary Tourists. Current Issues in Tourism, 9(3), 235-255. doi: $10.2167 / \mathrm{cit} / 229.0$

Kalenjuk, B., \& Tešanović, B. (2013). Određivanje pravaca strategijskog razvoja gastronomskog turizma u Vojvodini. Ekonomika, 59(4), 195-202. In Serbian.

Kalenjuk, B., Đerčan, B., \& Tešanović, D. (2012). Gastronomski turizam kao faktor regionalnog razvoja. Ekonomika, 58(3), 136-146. In Serbian.

Kalenjuk, B., Tešanović, D., \& Gagić, S. (2014). Regionalni razvoj turističkih destinacija kroz razvoj gastronomskog turizma. In: Od krize prema razvoju: 4. Međunarodna naučna konferencija. (pp. 363-374). BIH: Univerzitet za poslovne studije. In Serbian.

Kalenjuk, B., Tešanović, D., Rudić, Lj., Korbatfinski, M., Gagić, S. \& Vuksanović, N. (2012). Gastronomski potencijal severne Bačke u funkciji gastronomskog turizma. In: Zbornik radova Departmana za geografiju, turizam i hotelijerstvo. (pp. 337-349). Novi Sad: Prirodno-matematički fakultet. In Serbian.

Kalenjuk, B., Tešanović, D., Škrinjar, M., \& Đeri, L. (2012). The importance of authentic food in the development of the culinary tourism in Vojvodina. In: Belgrade International Tourism Conference - BITCO Contemporary tourism, wishes \& opportunities. (pp. 293-300). Belgrade: College of tourism.

Kalenjuk, B., Tešanović, D., Škrinjar, M., \& Vuksanović, N. (2011). Gastronomski potencijali Vojvodine u funkciji razvoja turizma. In: Zbornik radova Departmana za geografiju, turizam i hotelijerstvo. (pp. 180-187). Novi Sad: Prirodno-matematički fakultet. In Serbian.

Long, L.M. (2004). Culinary Tourism. Lexington: University Press of Kentucky.

McKercher, B., Okumus, F., \& Okumus, B. (2008). Food tourism as a viable market segment: It's all how you cook the numbers. Journal of Travel \& Tourism Marketing, 25(2), 137-148. doi:10.1080/10548400802402404

Meler, M., \& Cerovic, Z. (2003). Food marketing in the function of tourist product development. British Food Journal, 105(3), 175-192.

Sung, P.S., Uysal, M., \& McLellan, W.R. (1991). A linear expenditure model for tourism demand. Annals of Tourism Research, 18(3), 443-454. doi:10.1016/01607383(91)90051-C 
Quan, S., \& Wang, N. (2004). Towards a structural model of the tourist experience: An illustration from food experiences in tourism. Tourism Management, 25(3), 297-305.

Richards, G. (2002). Gastronomy: An essential ingredient in tourism production and consumption. In A.-M. Hjalager \& G. Richards (Eds.), Tourism and Gastronomy. (pp. 3-20). London: Routledge.

Santich, B. (2004). The study of gastronomy and its relevance to hospitality education and training. International Journal of Hospitality Management, 23(1), 15-24. doi:10.1016/ S0278-4319(03)00069-0

Stojanović, T., \& Čerović, S. (2008). Značaj gastronomske ponude za razvoj seoskog turizma Srbije. In: Zbornik radova: Geografski fakultet Univerziteta u Beogradu, br. 56. (pp. 165-176). In Serbian.

Tešanović, D., Kalenjuk, B., \& Vuksanović, N. (2010). Svečani obroci - značajan segment turističkog proizvoda na rečnim brodovima. Turističko poslovanje, 5, 251-262. In Serbian.

\section{PONUDA AUTENTIČNE HRANE KAO PREDUSLOV ZA RAZVOJ GASTRONOMSKOG TURIZMA}

\section{Rezime:}

Posmatrajući hranu kao značajan deo turističke ponude, sa aspekta bioloških potreba turista, postavlja se pitanje, na koji način ona može biti dodatno iskorišćena, i tako doprineti razvoju turizma. Sa tim u vezi hrana pripremljena od lokalnih namirnica, po starim metodama obrade i njihovo serviranje na autentičan način mogu biti zanimljivi turistima selektivnog oblika turizma, u svetu poznatog kao turizam hrane, gastronomski turizam i gurmanski turizam. Istraživanje ima cilj da prikaže ponudu hrane u ugostiteljstvu Vojvodine i da li ona kao takva može da zadovolji interesovanja stranih turista koji putuju zbog nje. Istraživanje je sprovedeno u 147 ugostiteljskih objekata za pružanje usluga ishrane i pića na teritoriji AP Vojvodine, direktnim i indirektnim sakupljanjem pisanih ponuda, pri čemu je obuhvatilo statističku analizu od 10.923 jela. Cilj rada jeste da se ukaže na trenutno stanje gastronomske ponude i sve prednosti autentične hrane i gastronomskog turizma.

\section{Ključne reči:}

hrana, gastronomija, turizam, gastronomski turizam.

Received: September 1, 2015. Correction: September 15, 2015. Accepted: October 6, 2015. 